\title{
Marketed as OTC Monograph Drug Product Manufactured Exclusively for Private Label Distributor
}

National Cancer Institute

\section{Source}

National Cancer Institute. Marketed as OTC Monograph Drug Product Manufactured

Exclusively for Private Label Distributor. NCI Thesaurus. Code C95601.

A marketing category specifying that an OTC monog raph drug product is manufactured and packaged exclusively for a Private Label Distributor, and not otherwise marketed by the drug product's manufacturer. 